\title{
Disagreements in the Approach to the NO Neck and their Causes in Head and Neck Cancers
}

\author{
Baş Boyun Kanserlerinde, No Boyuna Yaklaşımda Fikir Ayrılıkları \\ ve Nedenleri \\ (1) Aylin Eryılmaz, (1) Yeşim Başal \\ Aydın Adnan Menderes University Faculty of Medicine, Department of Otorhinolaryngology, Aydın, Turkey
}

Keywords

Head and neck cancers, N0, approach

Anahtar Kelimeler

Baş boyun kanserleri, N0, yaklaşım

Received/Geliş Tarihi : 21.03.2016

Accepted/Kabul Tarihi : 13.04.2016

doi:10.4274/meandros.galenos.2016.2781

Address for Correspondence/Yazışma Adresi: Aylin Eryılmaz MD,

Aydın Adnan Menderes University Faculty of Medicine, Department of Otorhinolaryngology, Aydın, Turkey

E-mail : draylineryilmaz@gmail.com

ORCID ID: orcid.org/0000-0002-1417-7267

(C) Meandros Medical and Dental Journal, Published by Galenos Publishing House.

This is article distributed under the terms of the

Creative Commons Attribution NonCommercial 4.0

International Licence (CC BY-NC 4.0).

\begin{abstract}
There are numerous controversial issues in the management of patients with N0 neck. Whether the diagnosis of NO neck should be made based on the physical examination or imaging methods is contradictory in the first place. The rates of metastasis to the neck and the identification of occult neck metastasis vary according to the location and histopathological characteristics of the primary tumour. A wait-and-see approach may be preferred in the treatment of these patients, whereas an elective neck dissection or elective radiotherapy may be implemented considering all these features. An elective treatment is preferred if the occult metastasis ratio is higher than 15-20\%. The neck dissection levels change depending on the primary tumour localisation. In patients with NO neck, it is required to decide on the most effective prophylactic treatment with low morbidity that can avoid cervical recurrence and distant metastasis.
\end{abstract}

Öz

Baş boyun kanserlerinde, NO boyunlu hastalara yaklaşımda birçok tartışmalı konu bulunmaktadır. Başta N0 tanısının, muayeneye göre mi, görüntüleme yöntemlerine göre mi konulacağı tartışmalıdır. Primer tümörün yerleşim yerine ve histopatolojik özelliklerine göre boyuna metastaz yapma ve boyunda okült metastaz saptanma oranları değişmektedir. Tüm bu özellikler gözetilerek, bu hastaların tedavisinde, bekle-gör şeklinde bir yaklaşım olabildiği gibi, elektif boyun diseksiyonu veya elektif radyoterapi de uygulanabilmektedir. Boyunda gizli metastaz olasılığı \%1520'nin üzerinde ise elektif tedavi önerilmektedir. Elektif boyun diseksiyonlarında primer tümöre göre diseke edilecek lenf nodu bölgeleri değişmektedir. NO olan hastalarda, boyun nüksü ve uzak metastazdan koruyan en etkin ve morbiditesi düşük profilaktik tedaviye karar vermek gerekmektedir. 


\section{Introduction}

Patients defined as NO in head and neck cancers are the patients in whom the pathological lymph nodes are considered to be absent clinically by the examination and the imaging methods. During the decision-making in the NO neck, the size, the histopathological features, the degree of differentiation, and the location of the tumor have importance (1). Whether there are cancer cells in the lymph nodes and occult metastasis is present or not are significant indeterminate issues in patients defined as NO (1). The probability of development of clinical cervical metastasis in the future, and when identified, how many of these would benefit from the salvage surgery are also important. The cervical metastases are among the significant causes of death following treatment of head and neck cancers. During the decision-making process for treatment, our primary principle is "Primum non nocere", doing no harm to the patients, first.

In patients with NO neck, it is required to decide on the most effective prophylactic treatment with low morbidity that can avoid cervical recurrence and distant metastasis, during decision-making.

\section{Imaging in the NO Neck}

First of all, we consider that NO being related to what is an important issue. Will we consider these patients $\mathrm{NO}$ according to findings on palpation, imaging methods, or the result of the ultrasound- guided fine needle aspiration biopsy? When the results of the computed tomography (CT) only were compared to the magnetic resonance imaging (MRI), they were found to have similar sensitivities (sensitivity: metastasis+, finding+) and specificities (specificity: finding-, disease-) (2). CT, MRI, ultrasonography, positron emission tomography (PET) and palpation are methods used in diagnosing NO (1). Besides all these, the ultrasound-guided fine needle aspiration biopsy was emphasized to be important in the diagnosis of NO (1-3). The specificity of positron emission tomography is high (82-85\%) in this respect; however, the sensitivity is significantly reduced (50-70\%) in NO necks when compared to the $\mathrm{N}+$ ones. Therefore, in NO patients, PET was considered as unnecessary concerning neck in NO patients (4). However, since the stage and the treatment plan might change with PET, it is recommended in T3 and T4 patients. Some suggest using the clinical criteria only, not recommending any imaging method. Suggesting that elective neck dissection can be performed in T2 patients even though no lymph node is identified by imaging, and also, in T1 patients, the detected lymph node does not always imply metastasis, the proponents of this argument do not recommend imaging.

\section{The Therapeutic Approaches}

They can be performed as a wait-and-see procedure or a prophylactic/elective treatment [neck dissection (ND), radiotherapy (RT)] (1). The elective treatment can contribute the staging and therapeutic processes (Figure 1) (1).

\section{Wait-and-see}

Those who accept this therapeutic approach consider that cancer is not present in the lymph nodes of the patients recognized as NO clinically. They advocate that salvage surgery can be implemented if cervical metastasis is determined in the future. This approach is accepted if the probability of occult metastasis in under $20 \%$. One of the disadvantages of this approach is the probability of being unable to identify the cervical metastasis early, in the future. When it is identified, the pathological stage might be more advanced than the clinical stage. The salvage treatments have not been very successful. Besides,

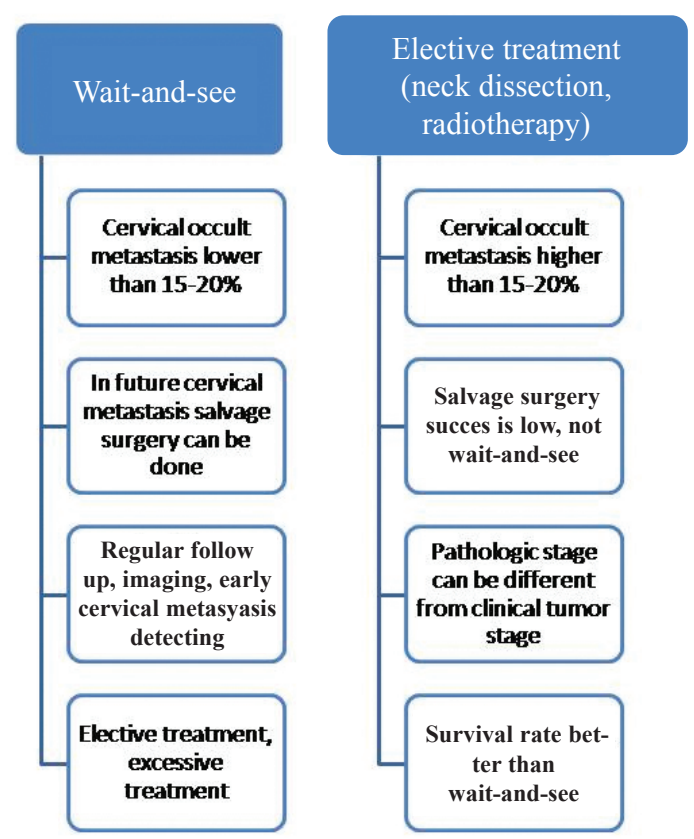

Figure 1. The advantages of treatment options in N0 neck 
when cervical metastasis develops, the probability of developing distant metastasis is also elevated. The situations that the wait-and-see approach is not appropriate are as follows: the location of the primary tumor, the likelihood of the occult cervical metastasis being greater than $15-20 \%$ related to its stage, the neck being short and thick, the unavailability of medical center resources for frequent imaging, the inability of the patient to attend regular follow-up examinations, and failure to perform immediate salvage surgery (5).

\section{The Elective Treatment}

The advocates of this approach consider that even though the patient is NO clinically, occult metastases might be present in the neck region. Since the success rate of the salvage surgery is small, they defend the necessity of the elective treatment. One of the hesitations of supporters of this treatment is whether the elective surgery would be an excessive treatment if these patients are actually NO. It is recommended that if elective surgery is performed in NO neck, the method should be similar to the method used in the primary tumor (surgery or RT) for the patient not to undertake the morbidities of both methods. The prophylactic RT is considered to be as effective as surgery. In NO neck, the surgical treatment is "selective ND" [lateral ND, selective ND (II-IV)]. The type of the selective ND is decided depending on the lymph nodes at risk. The survival rate was determined to be higher in patients who had undergone ND during the neck was in the occult state when compared to those who had undergone surgery following the occurrence of the clinical findings $(6,7)$. While some authors have suggested that the success of the elective RT was similar to that of elective ND (8), others have stated that the cervical recurrence was more frequent following elective RT when compared to ND (9). In a high-grade tumor, elective RT might be preferred if RT is planned following surgery.

\section{NO According to the Location of the Tumor}

A high rate of clinical $\mathrm{N}$-positivity has been determined in cancers of the tongue corpus, the mouth floor, the retromolar trigone, gingiva, nasopharynx, oropharynx, and the supraglottic larynx, even at the time of the diagnosis (1). The identification rate of occult cervical metastasis is high in cancers of the tongue corpus and base, the mouth floor, gingiva, pharyngeal walls, hypopharynx, and the supraglottic larynx, even though the patient is NO clinically (5).

In oral cavity tumors, the tumor thickness in $\mathrm{T} 1$ $\mathrm{T} 2$ is quite significant concerning our decision for treatment. It was determined that the elective ND had contributed to the survival positively in tumors with at hickness of $4 \mathrm{~mm}$ and above (10). If the depth is over 3-4 $\mathrm{mm}$, the risk of occult metastasis rises to $40 \%$ or more in the oral cavity tumors (11).

While the incidence of occult metastasis was $10 \%$ in the glottic tumors which were NO both initially and following treatment, this rate is over $40 \%$ in the supraglottic and transglottic tumors (12). The risk of the occult metastasis development is directly proportional to the T stage (13).

Numerous studies have reported rates ranging from $4 \%$ to $25 \%$ for occult metastasis in lower lip cancers. There are studies suggesting that occult metastasis rates are in parallel with the T stage or stating that the two are not related (14). These ratios are not always related to the tumor size. The skip metastases are important. In NO patients with lower lip pathologies who undergo suprahyoid ND, recurrence might be observed in zone 3. While the wait-and-see approach is recommended in T1N0 patients in lip tumors, some authors have suggested performing suprahyoid or supraomohyoid NDs in T2-3 NO and the commissure (15). However, an important issue is that when T1 patients are admitted with cervical recurrence, although rare, their salvage surgeries are quite complicated. In tongue tumors, the rate of occult metastasis is high. While some authors have suggested elective ND even if the patient was T1, some others have stated that in $\mathrm{T} 1, \mathrm{~T} 2$ and NO patients, the success rates of the observation and the elective ND approaches were similar, the ND not providing any therapeutic contribution (16-19). However, in T1, the contralateral ND is not recommended. The probability of contralateral neck metastasis increases when the tumor passes the midline, and the ipsilateral neck is positive.

The perineural invasion, singly, is an important indicator related to the occult metastasis and the regional recurrence (20).

\section{Why Bilateral Neck Dissection in NO?}

It is recommended in midline lesions. The supraglottis is considered as a midline structure embryologically; however, when the lesion is laterally located, the ipsilateral ND may be initially performed. 
The authors criticizing the routine bilateral implementation have advocated that the disruption of the integrity of the lymph nodes would destroy the barrier against cancer, it the cancer is not present. The prevalence of contralateral metastasis is under $10 \%$ in supraglottic cancer, in $\mathrm{T} 1, \mathrm{~T} 2$, and unilateral pathologic NO (5). Therefore, in unilateral pathologic NO tumor, the contralateral ND might not be performed. However, one of the significant hesitations is which side of the neck should be dissected first. It is suggested that this should be decided depending on the lateralization of the lesion or the presence of the sentinel node. However, as a counter-view, lateterm contralateral metastases have been reported in unilateral NO cases (21).

Although some authors have suggested that contralateral ND should be performed when the suspicious lymph node was reported as $\mathrm{N}+$ in frozen section during the ND, since the entire neck cannot be examined by frozen section, the suspicious lymph not might not be encountered. Elective RT might be administered to the contralateral side, or when the pathology report reveals $\mathrm{N}+$, contralateral ND might be performed. RT should not be preferred particularly in conservative laryngeal surgery.

\section{The Advantages of Selective Neck Dissections}

It is an oncologically effective method. The lymph nodes that are at risk are excised. Since the sternocleidomastoid muscle, the accessory nerve, and the jugular vein are preserved, its morbidity is low. Its bilateral implementation can be made simultaneously. The pathological staging together with the prognostic evaluation and requirements for additional treatments can be planned correctly. Provision of additional treatment may occur in NO cases following the ND. It may be necessary to initiate detailed ND according to the findings and frozen section results during surgery. The preservation of the submandibular gland during ND is one of the controversial issues $(22,23)$. Since it does not involve intraparenchymal lymph nodes, some authors recommend its preservation (22). However, due to the proximity of the gland to the tumors of the mouth floor and tongue base, another opinion has been the non-preservation of the gland $(23,24)$. The preservation of the submandibular gland may lead to difficulties in the exposure of the lymph nodes located behind the gland.

\section{The NO Neck Results in Salvage Surgery}

There are differences in approaching the clinically NO cases with recurrent laryngeal carcinoma. The wait-and-see approach, additional RT, or selective ND might be performed. It was determined that these therapeutic approaches were not able to create any significant differences in the survival rates (25).

\section{Dissection of Zone IV?}

Some of the significant morbidities during the dissection of this zone are the probability of chylous fistula and phrenic nerve injury development. The situations in which the development of zone IV metastasis is possible to occur are the subglottic extension from the larynx and the transglottic tumors (26). In clinically NO necks, the zone IV metastasis occurs with low rates such as $0-3.5 \%$ following the treatment. In numerous studies, the zone IV metastasis was always identified together with zone II or zone III metastases. Therefore, it has been suggested that zone II and zone III might be sent to the frozen-section examination and when the result was reported as (+), the zone IV dissection might be performed (26). The regional recurrences were reported to be frequent in zone IV (27). In oropharyngeal cancers, since skip metastasis is frequently met in zone IV, the dissection of this zone has been recommended (27).

The Dissection of Zone IIb in NO Laryngeal and Hypopharyngeal Cancers?

In zone Ilb dissections performed in the clinically $\mathrm{NO}$ and $\mathrm{N}+$ necks, the metastasis to zone Ilb was identified as $1-17 \%$. The most significant morbidity in the dissection of zone $\mathrm{Ilb}$ is the accessory nerve dysfunction. In NO laryngeal cancers, the dissection of the zone Ilb has not been recommended $(28,29)$. In cancers of the tongue, zone $\mathrm{llb}$ dissection is recommended (30).

\section{The Dissection of Zone V}

While the involvement of zone $\mathrm{V}$ is $1 \%$ in No head and neck cancers, the rate increases up to $7 \%$ in the cancers of hypopharynx and oropharynx. In parotid tumors, the dissection of zone $\mathrm{V}$ is not recommended in NO cases (31).

The Use of the Sentinel Node in Head and Neck

The sentinel node has been introduced to routine use in the malignant melanomas of the head and neck regions; it has significant contributions concerning the staging process (32). The false-positivity rates are high, and the false-negativity rates are low in 
the histopathological examination of the sentinel nodes. During its use in the oral cavity and the oropharynx, the negative predictive value of the sentinel node is $94-95 \%$ (33). One of the controversial issues is the examination of the sentinel node by immunohistochemical methods, after staining by haematoxylin-eosin, instead of frozen-section examination. Here, the significant question mark is the probability of skip metastasis.

\section{Conclusion}

In head and neck cancers, the appropriate treatment can be decided by taking into consideration the findings of the physical examination and the imaging methods, the location of the primary tumor, the histopathological characteristics of the primary tumor, the $T$ stage and the comorbidities of the patient while approaching the NO neck.

Peer-review: Externally and internally peerreviewed.

\section{Authorship Contributions}

Concept: A.E., Y.B., Design: A.E., Y.B., Data Collection or Processing: A.E., Analysis or Interpretation: A.E., Y.B., Literature Search: A.E., Writing: A.E., Y.B., Critical Review: A.E., Y.B.

Conflict of Interest: No conflict of interest was declared by the authors.

Financial Disclosure: The authors declared that this study received no financial support.

\section{References}

1. Pillsbury $\mathrm{HC}$, Clark M. A rationale for therapy of the NO neck. Laryngoscope 1997; 107: 1294-315.

2. de Bree R, Takes RP, Castelijns JA, Medina JE, Stoeckli SJ, Mancuso AA, et al. Advances in diagnostic modalities to detect occult lymph node metastases in head and neck squamous cell carcinoma. Head Neck 2015; 37: 1829-39.

3. Flach GB, Tenhagen $M$, de Bree R, Brakenhoff RH, van der Waal I, Bloemena $E$, et al. Outcome of patients with early stage oral cancer managed by an observation strategy towards the NO neck using ultrasound guided fine needle aspiration cytology: No survival difference as compared to elective neck dissection. Oral Oncol 2013; 49: 157-64.

4. Nguyen A, Luginbuhl A, Cognetti D, Abel KV, Bar-Ad V, Intenzo C, et al. Effectiveness of PET/CT in the preoperative evaluation of neck disease. Laryngoscope 2014; 124: 159-64.

5. Levent Erişen. Baş Boyun Kanserleri. Baş Boyun Kanserlerinde Boyuna Yaklaşım. 2003 Nobel; 439-502.
6. Fasunla AJ, Greene BH, Timmesfeld N, Wiegand S, Werner JA, Sesterhenn AM. A meta-analysis of the randomized controlled trials on elective neck dissection versus therapeutic neck dissection in oral cavity cancers with clinically node-negative neck. Oral Oncol 2011; 47: 320-4.

7. Huang SF, Chang JT, Liao CT, Jan Kang C, Lin CY, Fan KH, et al. The role of elective neck dissection in early stage buccal cancer. Laryngoscope 2015; 125: 128-33.

8. Chow JM, Levin BC, Krivit JS, Applebaum EL. Radiotherapy or surgery for subclinical cervical node metastases. Arch Otolaryngol Head Neck Surg 1989; 115: 981-4.

9. Al-Rajhi N, Khafaga Y, El-Husseiny J, Saleem M, Mourad W, Al-Otieschan A, et al. Early stage carcinoma of oral tongue: prognostic factors for local control and survival. Oral Oncol 2000; 36: 508-14.

10. Ebrahimi A, Ashford BG, Clark JR. Improved survival with elective neck dissection in thick early-stage oral squamous cell carcinoma. Head Neck 2012; 34: 709-16.

11. Po Wing Yuen A, Lam KY, Lam LK, Ho CM, Chow TL, Yuen WF, et al. Prognostic factors of clinically stage I and II oral tongue carcinoma-A comparative study of stage, thickness, shape, growth pattern, invasive front malignancy grading, MartinezGimeno score, and pathologic features. Head Neck 2002; 24 : 513-20.

12. Koss SL, Russell MD, Leem TH, Schiff BA, Smith RV. Occult nodal disease in patients with failed laryngeal preservation undergoing surgical salvage. Laryngoscope 2014; 124: 421-8.

13. Ma H, Lian M, Feng L, Li P, Hou L, Liu H, et al. Management of cervical lymph nodes for cNO advanced glottic laryngeal carcinoma and its long-term results. Acta Otolaryngol 2014; 134 : 952-8.

14. An SY, Jung EJ, Lee M, Kwon TK, Sung MW, Jeon YK, et al. Factors related to regional recurrence in early stage squamous cell carcinoma of the oral tongue. Clin Exp Otorhinolaryngol 2008; 1: $166-70$.

15. Altinyollar $\mathrm{H}$, Bulut $\mathrm{H}$, Berberoglu $\mathrm{U}$. Is suprahyoid dissection a diagnostic operation in lower lip carcinoma? J Exp Clin Cancer Res 2002; 21: 29-30.

16. Peng KA, Chu AC, Lai C, Grogan T, Elashoff D, Abemayor E, et al. Is there a role for neck dissection in $\mathrm{T} 1$ oral tongue squamous cell carcinoma? The UCLA experience. Am J Otolaryngol 2014; 35: 741-6.

17. Ünsal Tuna EE, Özdem C. T1-T3 NO oral dil kanserlerinde boyun lenfatik bölgelerinde metastazın araştrılması. Kbb-forum 2009; 8.

18. Iqbal $H$, Bhatti $A B$, Hussain $R$, Jamshed $A$. Regional failures after selective neck dissection in previously untreated squamous cell carcinoma of oral cavity. Int J Surg Oncol 2014; 2014: 205715.

19. Ord RA. Surgical management of the NO neck in early stage T1-2 oral cancer; a personal perspective of early and late impalpable disease. Oral Maxillofac Surg 2012; 16: 181-8.

20. Chinn SB, Spector ME, Bellile EL, McHugh JB, Gernon TJ, Bradford $\mathrm{CR}$, et al. Impact of perineural invasion in the pathologically NO neck in oral cavity squamous cell carcinoma. Otolaryngol Head Neck Surg 2013; 149: 893-9. 
21. Yılmaz T, Süslü N, Atay G, Günaydın RÖ, Bajin MD, Özer S. The effect of midline crossing of lateral supraglottic cancer on contralateral cervical lymph node metastasis. Acta Otolaryngol 2015; 135: 484-8.

22. Guney E, Yigitbasi OG. Functional surgical approach to the level I for staging early carcinoma of the lower lip. Otolaryngol Head Neck Surg 2004; 131: 503-8.

23. Ebrahim AK, Loock JW, Afrogheh A, Hille J. Is it oncologically safe to leave the ipsilateral submandibular gland during neck dissection for head and neck squamous cell carcinoma? J Laryngol Otol 2011; 125: 837-40.

24. Lanzer M, Gander T, Lübbers HT, Metzler P, Bredell M, Reinisch S. Preservation of ipsilateral submandibular gland is ill advised in cancer of the floor of the mouth or tongue. Laryngoscope 2014; 124: 2070-4.

25. Basheeth N, O'Leary G, Sheahan P. Elective neck dissection for no neck during salvage total laryngectomy: findings, complications, and oncological outcome. JAMA Otolaryngol Head Neck Surg 2013; 139: 790-6.

26. Elsheikh MN, Ferlito A, Rinaldo A, Shaha AR, Khafif A, Coskun HH, et al. Do pathologic and molecular analyses of neck dissection specimens justify the preservation of level IV for laryngeal squamous carcinoma with clinically negative neck? J Am Coll Surg 2006; 202: 320-3.
27. Lim YC, Koo BS, Lee JS, Lim JY, Choi EC. Distributions of cervical lymph node metastases in oropharyngeal carcinoma: therapeutic implications for the NO neck. Laryngoscope 2006; 116: 1148-52.

28. Coskun HH, Erisen L, Basut O. Selective neck dissection for clinically NO neck in laryngeal cancer: is dissection of level Ilb necessary? Otolaryngol Head Neck Surg 2004; 131: 655-9.

29. Gross BC, Olsen SM, Lewis JE, Kasperbauer JL, Moore EJ, Olsen $K D$, et al. Level IIB lymph node metastasis in laryngeal and hypopharyngeal squamous cell carcinoma: single-institution case series and review of the literature. Laryngoscope 2013; 123: 3032-6.

30. Maher NG, Hoffman GR. Elective neck dissection for primary oral cavity squamous cell carcinoma involving the tongue should include sublevel Ilb. J Oral Maxillofac Surg 2014; 72: 2333-43.

31. Lim CM, Gilbert M, Johnson JT, Kim S. Is level V neck dissection necessary in primary parotid cancer? Laryngoscope 2015; 125: 118-21.

32. Schmalbach CE, Bradford CR. Is sentinel lymph node biopsy the standard of care for cutaneous head and neck melanoma? Laryngoscope 2015; 125: 153-60.

33. Flach GB, Bloemena E, Klop WM, van Es RJJ, Schepman KP, Hoekstra OS, et al. Sentinel lymph node biopsy in clinically NO T1-T2 staged oral cancer: the Dutch multicenter trial. Oral Oncol 2014; 50: 1020-4. 